\title{
KNOWLEDGE, ATTITUDE AND PRACTICES ON USE OF TOBACCO USE IN ADOLESCENT STUDENTS IN WARANGAL DISTRICT, ANDHRA PRADESH
}

\author{
Rajmouli Jannu1 ${ }^{1}$ Punam Kumari Jha², Muraleedhar ${ }^{3}$
}

\section{HOW TO CITE THIS ARTICLE:}

Rajmouli Jannu, Punam Kumari Jha, Muraleedhar. "Knowledge, attitude and practices on use of tobacco use in adolescent students in Warangal district, Andhra Pradesh". Journal of Evolution of Medical and Dental Sciences 2013; Vol2, Issue 38, September 23; Page: 7293-7296.

OBJECTIVES: To study the existing level of knowledge among college students regarding smoking and other modes of tobacco use. MATERIALS AND METHODS: A cross-sectional survey done on 600 adolescent college students. Both Government and Private Colleges students of Warangal district were included. The age group of student was from 16 to 18 years. RESULTS: Out of 600 students, 424 were males and 176 were females. Among study group 25.8\% having smoking habit. Reason given for smoking is that majority want just to enjoy. $84 \%$ of the study group wants banning of tobacco use in public places. CONCLUSIONS: The majority of students have the knowledge and awareness about toxic effect of tobacco products using and its warning about smoking. Reason showing to become smokers is from association of smoking parents and smoking friends circle.

KEY WORD: Tobacco, smoking, students.

INTRODUCTION: Tobacco use is the single most preventable cause of adult death and disease in the world today. The Prevention of tobacco use in young (teen) age people is a greatest opportunity to prevent the non-communicable disease and cause of death all over the world. Currently World Health Organization estimated that there are 1.3 billion smokers in the world. The death toll from tobacco consumption is 4.9 million per year i.e., on in 10 adult deaths worldwide and per every 10 seconds a person dies of tobacco use. If proper action is not taken the number of deaths will increase to 10 million by year $2020 .{ }^{1}$ Of which $70 \%$ (7 millions) death will occur in developing countries mainly in China and India.

The Portuguese introduced tobacco in India only in 17th century, but within short period its use spread all over the country. The two major modes of tobacco use in India, are smoking and non smoking form. India was one of the first-countries in the world to report the adverse health consequences of tobacco. World Health Organization, United States, Centers for Disease Control and Prevention (CDC), and the Canadian Public Health Association (CPHA) developed the Global Tobacco Surveillance System (GTSS) to assist all 192 WHO member states in establishing continuous tobacco control Surveillance and Monitoring. ${ }^{2}$

MATERIALS AND METHODS: The present study is conducted on knowledge, Attitude and Practices of tobacco use in Junior College Students of Warangal District. The subjects taken for the study are from 20\% of 49 Government Junior Colleges (10 Colleges) and 20\% from Aided Junior Colleges (2Colleges). The total subjects taken for this study are 600 students 432 males and 168 females. The age group is 16 to 18 years.

The study extends from October, 2005 to September, 2006 involving planning, preparation of proforma, testing of proforma, and collection of data, analysis and presentation. 
The data was collected through using pre-designed and pretested close ended questionnaire. The study is cross sectional in nature. A random sample of 12 colleges from 60 Government Colleges under Kakatiya University was selected. From each college samples of 50 students were taken covering both English and Telugu medium based on Quota sampling. Before taking up the actual survey pilot study was conducted on 40 students and suitable modification were made to the questionnaire.

RESULTS: The data collected from 600 students was analysed and tabulated by using a computer.

\begin{tabular}{|c|l|c|c|c|}
\hline Sl. No. & \multicolumn{1}{|c|}{ Questions } & $\begin{array}{c}\text { Correct } \\
\text { Answers }\end{array}$ & Wrong Answers & Not Attempted \\
\hline 1. & Tobacco cultivation District & $236(39.33 \%)$ & $323(58.83 \%)$ & $41(6.83 \%)$ \\
\hline 2. & Obtaining raw tobacco & $449(74.83 \%)$ & $106(17.66 \%)$ & $45(7.50 \%)$ \\
\hline 3. & Tobacco Consumption Harmfulness & $349(58.16 \%)$ & $234(39 \%)$ & $17(2.83 \%)$ \\
\hline 4. & Common Consumption in the world & $514(85.66 \%)$ & $18(3 \%)$ & $28(4.66 \%)$ \\
\hline 5. & Toxic content of Tobacco & $355(59.16 \%)$ & $174(29.8 \%)$ & $71(11.83 \%)$ \\
\hline 6. & Tobacco products uses \& Diseases & $132(22 \%)$ & $450(75 \%)$ & $18(3 \%)$ \\
\hline 7. & Tobacco effect on Pregnant Woman & $95(15.83 \%)$ & $480(80 \%)$ & $25(4.16 \%)$ \\
\hline 8. & Smoking addiction & $403(67.16 \%)$ & $193(32.16 \%)$ & $4(0.66 \%)$ \\
\hline 9. & Tobacco ban country & $229(38.16 \%)$ & $294(49 \%)$ & $77(12.83 \%)$ \\
\hline 10. & Treatment for smoking addiction & $270(45 \%)$ & $265(44.16 \%)$ & $65(10.83 \%)$ \\
\hline
\end{tabular}

Table 1: Knowledge on Tobacco and its products use among the study group ( $\mathrm{n}=600)$

\begin{tabular}{|c|c|c|c|c|c|}
\hline Sex & Gutka & Jardha & Cigarette & Not responded & Total \\
\hline Male & 20 & 40 & 136 & 218 & 414 \\
\hline Female & 13 & 31 & 19 & 123 & 186 \\
\hline Total & 33 & 71 & 155 & 341 & 600 \\
\hline
\end{tabular}

Table 2: Different tobacco products use among the study group of Students $(n=600)$
$\mathrm{X}^{2}=32.36$
$\mathrm{DF}=3$
$\mathrm{P}<0.001$ (Significant)

\begin{tabular}{|c|c|c|c|c|c|}
\hline Sex & $\begin{array}{c}\text { Asking him to } \\
\text { stop smoking }\end{array}$ & $\begin{array}{c}\text { Ignoring the } \\
\text { smoker }\end{array}$ & $\begin{array}{c}\text { Informing to the } \\
\text { authority }\end{array}$ & $\begin{array}{c}\text { Go away from the } \\
\text { smoking place }\end{array}$ & Total \\
\hline Male & 332 & 18 & 22 & 63 & 435 \\
\hline Female & 114 & 10 & 19 & 32 & 175 \\
\hline Total & $446 \quad 28$ & 31 & 95 & 600 \\
\hline \multicolumn{5}{|r|}{$\begin{array}{r}\text { Table 3: Different Individual response towards the } \\
\text { smoker in society among the study group (n=600) }\end{array}$} \\
\hline
\end{tabular}

$\mathrm{X}^{2}=3.89 \quad \mathrm{DF}=3 \quad \mathrm{P}>0.10$ (Not Significant) 


\section{ORIGINAL ARTICLE}

Table 1 shows 39\% of the student only know about the cultivation of tobacco. $74 \%$ of students know about the obtaining of the tobacco product. P value is $<0.01$ (significant).

Table 2 Majority of student do not want to disclose their opinion. Only $47 \%$ of students came out and disclosed that they are using Gutka 5\%, Jarda 12.33\%, Cigarette 25.83\%. P<0.01 (significant).

Table 3: Among study group on tobacco smoking 74\% are expressing strong feeling against smoking and $15 \%$ of the study group avoiding the smokers. The attitude towards the smokers is same in both the sex groups.

In Table $4-14 \%$ of students are became smokers by feeling boredom $66.45 \%$ by force of friends and $18.07 \%$ has influence of film hero's.

DISCUSSION: The present study is conducted in college of Warangal District of Andhra Pradesh. There are not many studies one in this area for comparison.

Among 600 responded $70.66 \%$ boy $29.34 \%$ were girls. The students were between 16 years to 18 years of age of whom $66 \%$ were from rural areas.

In the present study 5\% students were taking Gutka, $12.33 \%$ were taking Jarda and $25.8 \%$ of students were taking cigarettes. Sinha et. al., study showed that $48.8 \%$ of students who currently used smokeless tobacco smoking at home was reported $30.8 \%(3,4)$

The percentage of young people using any tobacco produced ranged from a high of 33\% in Ukraine and Moscow to low about 10\% in south. (5) In present study 17\% of students were above 16 years of age. C.L. Backinger et. al., said that nearly $90 \%$ of adult smokers started smoking before the age of 18 years $(6,9,10)$.

Among present study group reasons given for smoking are majority (46\%) of them are smoking for pleasure and other $29 \%$ out of boredom and rest $24.5 \%$ to avoid frustration. In comparison Dr. Sherine Ismail show the reason for trying smoking at least was out of curiosity (60.8\%) Peer influence (29.6\%) and to act mature $9.6 \%$ (7).

In the present study $64 \%$ of student smokers expressed their desire to quit smoking. In comparison Sinha DN and Gupta reported that current smokers 66.4\% want to stop smoking and $59.1 \%$ tried to stop smoking during the past year $(3,4,12)$. Global Tobacco Youth Survey study reported that majority of young people currently smoking want to stop smoking and over two-thirds have tried to stop ${ }^{(5,13)}$.

In the present study $84 \%$ of students among study group are positive attitude to make world tobacco free. By Global Youth Tobacco Survey study exposure of young people to environmental tobacco smoke is very high in all countries.

CONCLUSIONS: Tobacco use an important health problem in the world. The majority of students have the knowledge and awareness about toxic effects of tobacco products usage and its warning about smoking. Majority of student parent belong to low literacy status. The initiation of smoking is taking place below 10 years of age and maximum smokers above16 years. Majority from the student group are recommending for ban on tobacco products and they want tobacco free world(11,12,13). 


\section{REFERENCES:}

1. Doll R, Hill AB. Smoking and Carcinoma of lung, a global status report, Geneva WHO 1997.

2. Chaudary K. Prevalence of tobacco use in Karnataka and Uttar Pradesh in India. Indian Council of Medical Research, 2001.

3. Sinha DN, Gupta PC, Pednekar, MS. Use of tobacco products as dentfrice among adolescents in India: Questionnaire study. BMJ 2004 Feb 7: 328 (7835): 323-4.

4. Sinha DN Gupta P.C. Pednekar M.S. Prevalence of smoking and drinking among students in north Eastern India Natl. Med. J. India. 2003, Jan-Feb; 16(1): 49-50.

5. Warren CW Riley L. Asma S. et al. Tobacco use by youth a surveillance report from the GYTS Project. Bull. WHO 200: 78: 868-74.

6. C.L. Backunger P. Fagan et al: Adolescent and young adult tobacco Prevention and Cessation: Current status and future direction Atlanta American Cancer Society (1998).61-69.

7. Anjum Memon, Philip et. al., Epidemiology of Smoking among Kuwait adults: Prevalence, characteristic and Attitudes.89-93.1998.

8. Centers for Disease Control and Prevention: Medical-Care expenditures attributable to cigarette smoking - United States, 1993, MMWR 43(26): 469-472, 1994.

9. Coambs R.B. et. al. - Age interacts with heaviness of smoking in predicting success in cessation of smoking AM J Epidemiol. 1992; 135: 240-6.

10. Doll R, Peto R, et al. Prevalence of tobacco use in Britain; BMJ 2004; 328; 1519-33.

11. KAP study on tobacco uses in India; Indian Journal of Community Medicine; 2; 43-46, 2005.

12. Krishnan P, Mungheera et. al., Tobacco and Common Wealth: A call to action. Lancet 22003; 316: 1669-7.

13. McGinnis JM Foege WH; Actual causes of death in the United States JAMA 270 (18): 22072212 1993. Maxi.

\section{AUTHORS:}

1. Rajmouli Jannu

2. Punam Kumari Jha

3. Muraleedhar

\section{PARTICULARS OF CONTRIBUTORS}

1. Assistant Professor, Department of Community Medicine, Kakatiya Medical College, Warangal, A.P.

2. Present Professor \& HOD, Department of Community Medicine, Kakatiya Medical College, Warangal, Andhra Pradesh.

3. Former Professor \& HOD, Department of Community Medicine, Kakatiya Medical College, Warangal, Andhra Pradesh.

\section{NAME ADDRESS EMAIL ID OF THE CORRESPONDING AUTHOR:}

Dr. Punam Kumari Jha, Professor \& H.O.D, of Community Medicine, K.M.C, Warangal, A.P.

Email-drpunamjha@yahoo.co.in

Date of Submission: 04/09/2013.

Date of Peer Review: 05/09/2013.

Date of Acceptance: 13/09/2013.

Date of Publishing: 20/09/2013 